\title{
Anticachexia Agent
}

National Cancer Institute

\section{Source}

National Cancer Institute. Anticachexia Agent. NCI Thesaurus. Code C1935.

Drugs which reduce the fatigue and weight loss often associated with cancer. 